\title{
Bybelvertalers en Bybelvertalings die afgelope honderd jaar, in besonder vanuit die Fakulteit Teologie van die Universiteit van Pretoria
}

\begin{tabular}{|c|c|}
\hline \multicolumn{2}{|l|}{$\begin{array}{l}\text { Author: } \\
\text { Ananda B. }\end{array}$} \\
\hline \multicolumn{2}{|c|}{$\begin{array}{l}\text { Affiliation: } \\
\text { 'Department of Old } \\
\text { Testament Studies, Faculty of } \\
\text { Theology, University of } \\
\text { Pretoria, South Africa }\end{array}$} \\
\hline \multicolumn{2}{|c|}{$\begin{array}{l}\text { Research Project Registration: } \\
\text { Project Leader: A.B. } \\
\text { Geyser-Fouche } \\
\text { Project Number: } 1258230\end{array}$} \\
\hline \multicolumn{2}{|c|}{$\begin{array}{l}\text { Description: } \\
\text { This research is part of the } \\
\text { project 'Second Temple } \\
\text { Literature and Qumran', } \\
\text { directed by Dr Ananda } \\
\text { Geyser-Fouche, Department } \\
\text { of Old Testament Studies, } \\
\text { Faculty of Theology, } \\
\text { University of Pretoria. }\end{array}$} \\
\hline \multicolumn{2}{|c|}{$\begin{array}{l}\text { Corresponding author: } \\
\text { Ananda Geyser-Fouche, } \\
\text { ananda.geyser-fouche@up. } \\
\text { ac.za }\end{array}$} \\
\hline $\begin{array}{l}\text { Dates: } \\
\text { Received: } 21 \\
\text { Accepted: } 18 \\
\text { Published: } 07\end{array}$ & $\begin{array}{l}\text { uly } 2017 \\
\text { Aug. } 2017 \\
\text { Dec. } 2017\end{array}$ \\
\hline \multicolumn{2}{|c|}{$\begin{array}{l}\text { How to cite this article: } \\
\text { Geyser-Fouche, A.B., 2017, } \\
\text { 'Bybelvertalers en } \\
\text { Bybelvertalings die afgelope } \\
\text { honderd jaar, in besonder } \\
\text { vanuit die Fakulteit Teologie } \\
\text { van die Universiteit van } \\
\text { Pretoria', HTS Teologiese } \\
\text { Studies/Theological Studies } \\
\text { 73(1), a4741. https://doi. } \\
\text { org/10.4102/hts.v73i1.4741 }\end{array}$} \\
\hline \multicolumn{2}{|c|}{$\begin{array}{l}\text { Copyright: } \\
\text { (C) 2017. The Authors. } \\
\text { Licensee: AOSIS. This work } \\
\text { is licensed under the } \\
\text { Creative Commons } \\
\text { Attribution License. }\end{array}$} \\
\hline \multicolumn{2}{|l|}{ Read online: } \\
\hline 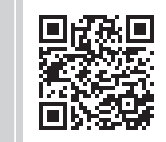 & $\begin{array}{l}\text { Scan this QR } \\
\text { code with your } \\
\text { smart phone or } \\
\text { mobile device } \\
\text { to read online. }\end{array}$ \\
\hline
\end{tabular}

With the 500 year celebration of the Reformation, it is necessary that Bible translation be reviewed again. The year 2017 is not only the year of Reformation celebration, but also the year of centenary celebration of the Faculty of Theology at the University of Pretoria (UP). The article attempts to briefly refer to the roots of Bible translation, which is anchored in the Reformation; but also to look at Bible translation in South Africa over the last hundred years, as well as the contribution made especially by the Faculty of Theology at the University of Pretoria (UP) in this regard.

\section{Inleiding}

Met die 500-jarige feesviering van die Reformasie is dit nodig dat Bybelvertaling weer in oënskou geneem word. Die jaar 2017 is nie net die jaar van Reformasieviering nie, maar ook die jaar van eeufeesviering van die Fakulteit Teologie aan die Universiteit van Pretoria (UP). ${ }^{1}$ Die artikel is 'n poging om vlugtig te verwys na die wortels van Bybelvertaling, ${ }^{2}$ wat in die Reformasie veranker is; maar om ook aandag te gee aan die verloop van Bybelvertaling in Suid-Afrika die afgelope honderd jaar asook die bydrae wat veral vanuit die Fakulteit Teologie aan die Universiteit van Pretoria (UP) op hierdie gebied gelewer is. Dit is dus net logies dat daar veral stilgestaan sal word by die leeueaandeel wat Prof J.P. Oberholzer reeds vanaf 1966 gehad het in Bybelvertaling en dat die nuutste verwikkelinge in Bybelvertaling ook aandag sal geniet.

\section{Reformasie}

John Wycliff word gewoonlik beskou as die voorloper vir die gedagte van 'n Bybel in 'n eie taal. Alhoewel sy vertaling nie uit die grondtale geskied het nie (hy het uit die Vulgaat vertaal - 1382) en Bybelvertaling ook as kettery beskou is, het hy tog die suggestie gelaat, wat later in die hervorming volledig gestalte sou vind (Chemorion 2009:1; Keating 2001:2). Die aanloop en motivering vir Wycliff se vertaling kan onder drie punte saamgevat word: Eerstens was daar sy pleidooi dat die kerklike wanpraktyke hervorm moes word; tweedens die versugting dat die Bybel die enigste norm moet wees; en derdens die besef dat daar 'n persoonlike aanspreeklikheid by gelowiges is. Hy het daarop gewys dat geen individu persoonlik aanspreeklik kan wees om die Bybel reg te verstaan, indien die Bybel in 'n taal is, wat hy of sy nie kan verstaan nie (Keating 2001:7-8). Net so het die drukpers en die druk van die Gutenberg-Bybel in 1455 die pad gebaan vir die Reformasie asook vir Bybelvertaling wat daarmee gepaard gegaan het (vgl Murray ${ }^{3}$ 2000:42; Smit 2015:178).

Labuschagne (2008:1191-1192) wys daarop dat die Reformasie wegbreek van die gearriveerde en finale denke van die Middeleeue en dat die keuse vir 'n terugkeer na die oorspronklike tekste in die plek van die Vulgaat nuwe insigte gebring het en ook uitgeloop het op'n kritiese Skrifbeskouing.

Wanneer daar oor die Reformasie en Bybelvertaling gepraat word, kan mens nie anders nie as om ook die naam van Martin Luther in herinnering te roep. Luther was oortuig daarvan dat die

\footnotetext{
1.Die Fakulteit Teologie van die Universiteit van Pretoria, herdenk in 2017 " $\mathrm{n}$ eeu lange bestaan. In honderd jaar het hierdie fakulteit aansienlik verander, ontwikkel en heelwat meegemaak. Hierdie geskiedenis vorm die agtergrond waarteen hierdie artikel geskryf is, maar die skopus van hierdie artikel maak dit onmoontlik om dit oor te vertel. Hierdie geskiedenis kan gelees word in Le Roux 1988; 2009; Oberholzer 2010a; 2010b; 2010c; 2010d; 2010e; 2010f; Van der Merwe (2016); Van der Merwe and Vos (2009); asook Van der Watt et al. (2009).
}

2.Sien Moore (2014) vir ' $n$ bespreking van die geskiedenis van Bybelvertaling

3.Murray (2000:42-43) beklemtoon wel dat dit meer as net die drukpers was wat aanleiding gegee het tot die reformasie, maar dat dit wel' $n$ beduidende bydrae gelewer het. Hy wys onder ander daarop dat die effek wat die drukpers kon hê om die Bybel aan Jan-alleman beskikbaar te stel, in die wiele gery is deur ongeletterdheid. Die Duitse reformatore se veldtogte vir geletterdheid sou wel later bydra om die Bybel aan almal beskikbaar te stel. 
Bybel vir elke gelowige verstaanbaar moet wees. Latyn wat in daardie tyd die taal van die kerk was, was vir die gemiddelde gelowige onverstaanbaar. Luther het eerstens die Nuwe Testament uit Grieks vertaal (1522). Hy en medewerkers het die Ou Testament uit Hebreeus en Aramees vertaal en in 1534 verskyn die hele Bybel in Duits. Luther en sy medewerkers het hierdie vertaling deurlopend hersien en her-vertaal (Moore 2014:81-82). Stolt (2014:377) benadruk die vertrekpunt en gesindheid waarmee Luther Bybelvertaling aangepak het: 'as a Bible translator, Luther is always in the first instance a responsible theologian.' Vir Luther was dit belangrik om die Bybel relevant te maak vir sy gehoor, sodat hy eerder gepoog het om idiomatiese uitdrukkings in die brontaal in die idioom van die teikentaal weer te gee, as om 'n letterlike woord-vir-woord vertaling te doen (vgl Steyn 2009:2; Stolt 2014:377). In hierdie verband verwys Steyn (2009:2) na Luther se eie woorde, waarvolgens hy sou gesê het dat hy daarna streef om Moses so Duits te maak, dat niemand sou vermoed het hy is 'n Jood nie; en dat vertalers na 'moeders in die huis'; 'kinders op straat'; en 'die gewone man op die mark' behoort te luister om te bepaal hoe die Bybel vertaal moet word (Steyn 2009:2). Stolt (2014:378) vertaal hierdie gesegde van Luther soos volg: '... one must ask the mother in the house, the children in the street, the common man in the market about this, and listen very closely how they speak and then translate accordingly so that they understand it and realize that one is speaking German to them.' ${ }^{4}$ In SuidAfrika het hierdie aspek later baie duidelik na vore gekom in die dinamies-ekwivalente Bybelvertalings.

\section{Bybelvertaling in Suid-Afrika Die Bybelvertaling in Suid-Afrika se amptelike tale}

Hermanson (2002) wys daarop dat daar in Suid-Afrika veral twee periodes van Bybelvertaling was:

(1) The Missionary Society Period, with formal-equivalent translations being made by missionaries, sometimes with Bible Society help towards the publishing costs, and (2) The Bible Society Period, with dynamic-/functional-equivalent translations being made by interdenominational translation teams, under the guidance and supervision of the Bible Society. (p. 7)

Met die sendelingvertalings is die Bybel in die meeste Afrika-tale van Suid-Afrika vertaal. Hermanson (2002:7-8) wys daarop dat alhoewel meeste sendelinge bedrewe was in Hebreeus, Grieks en Latyn, hulle nie noodwendig kundig was in vertaaltegnieke nie. Dit het meegebring dat heelwat van die vertalings woord-vir-woord eerder as idiomatiese vertalings was. Daar was wel vertalers wat 'n sensitiwiteit gehad het vir 'n meer idiomatiese vertaling, en wat dan moedertaalsprekers by die proses betrek het. Vertalers van hierdie era het ook in baie gevalle gesteun op bestaande vertalings sodat invloede van onder andere die 'English Authorised Version' in sekere gevalle duidelik sigbaar was. Die eerste Bybelboek in 'n inheemse taal word in 1830 in Kaapstad gedruk - die Lukasevangelie in Tswana (Steyn 1995:3).

4.WA 30/2:637.17-22: LW 35:189.
Steyn (1995:2-3) wys op die uitdagings wat hierdie sendelingvertalers trotseer het; die opofferings wat hulle moes maak en die onderbrekings wat dikwels verduur moes word. Hy wys ook op die pionierswerk wat hierdie persone moes doen met betrekking tot die grammatika en die gebrek aan 'n geskrewe taalsisteem van die inheemse tale.

In November 1965 het die Bybelgenootskap onafhanklik geword. Dit was in hierdie tyd wat dr E. A. Nida sy teorie van 'n dinamies-ekwivalente vertaling ontwikkel het. In 1967 is ds J.C.C. Pauw aangewys as die sekretaris van vertalings en in 1969 ds (later dr) J.L. Reyneke as die Vertalingsadviseur. Beide dr Nida en prof J.P. Louw het daartoe bygedra om die teorieë van dinamies-ekwivalente vertalings aan vertalingskomitees bekend te stel. Vertalings sou gedoen word deur 'n komitee wat gelei word deur 'n koördineerder. Die koördineerder moes teologies onderlê wees en kennis van sowel Hebreeus as Grieks, maar ook ervaring van die inheemse taal gehad het. Die komitee sou verder bestaan uit moedertaalsprekers wat nie noodwendig kennis van die grondtale gehad het nie (Hermanson 2002:9-10).

Bybelvertalings in Suid-Afrika se elf amptelike tale het soos volg plaasgevind: ${ }^{5}$

- 1853 in Engels.

- 1857 in Setswana onder leiding van die London Missionary Society deur Robert Moffat en in 1908 deur Wookey.

- 1859 in isiXhosa deur die Wesleyan Missionary Society en in 1864 deur Appleyard, hersien in 1899 en 1942.

- 1881 in Sesotho gedruk en in 1883 versprei deur die Paris Evangelical Mission en later hersien in 1899, 1909, 1961 en 1976.

- 1883 in isiZulu deur die American Zulu Mission (ABS) en later hersien in 1893 (wat steeds in druk is); nuwe vertaling is gedoen in 1924 deur Hermannsburg Mission, maar dit is gestaak; in 1924 is dit deur die Natal Missionary Conference (BFBS) gedoen.

- 1904 en 1951 in Sepedi deur die Berlin Mission.

- 1907(6) Xitsonga deur die Swiss Mission en hersien in 1929.

- 1933 in Afrikaans deur die Britse en Buitelandse Bybelgenootskap en hersien in 1953.

- 1936 Tshivenda deur Berlin Mission.

- 1970 in Sentraal-Setswana deur Hermannsburg and Dutch Reformed van Berlyn.

- 1983 in Afrikaans die Nuwe Afrikaanse Bybelvertaling deur die Bybelgenootskap van Suid-Afrika.

- 1996 Siswati deur die Bybelgenootskap van Suid-Afrika.

- 2012 isiNdebele deur die Bybelgenootskap van SuidAfrika.

Die IsiNdebele-vertaling was die laaste van Suid-Afrika se elf amptelike tale om 'n volledige Bybel in hulle eie taal te ontvang. Die taal word deur meer as seshonderduisend SuidAfrikaners gepraat. In 1977 was die eerste boek (die Evangelie webwerf van die Bybelgenootskap: www.bybel.co.za 
volgens Markus) in IsiNdebele vertaal en in 1986 het die eerste Nuwe Testament en 'n keur uit die Psalms verskyn, maar die volledige Bybelvertaling sou eers in 2012 die lig sien. ${ }^{6}$ Prof A.P.B. Breytenbach was die projekleier vir die vertaling van die Ou Testament, maar ook die brontaalkenner en eksegeet vir dié projek. Sy taalvermoë in Hebreeus en Aramees sowel as sy kennis van IsiNdebele het hom meer as bekwaam gemaak vir hierdie taak. Prof Breytenbach, pastoor David Mahlangu, en pastoor Peter Mabena het sedert 2000 voltyds aan die projek gewerk en daarna ook 'n grondige hersiening van die Nuwe Testament gedoen. Daar was 'n hersieningskomitee wat op gereelde basis die teks wat die vertalers voorberei het, nagegaan het en aanbevelings gemaak het (Turley 2012:1). Ds Gerrit Kritzinger het in 2014 met sy uittrede as Uitvoerende hoof van die Bybelgenootskap genoem dat dit een van die grootste hoogtepunte in sy loopbaan by die Bybelgenootskap was:

Wat 'n wonderlike voorreg om te kan sê dat al elf amptelike tale in Suid-Afrika nou oor die volledige Bybel beskik en dat ek hier kon wees vir hierdie besondere mylpaal. ${ }^{7}$

Breytenbach se kenmerkende presiesheid en werksetiek het daartoe bygedra dat hierdie vertaling een van die vertalings is wat werklik van hoë standaard getuig. In 'n video ${ }^{8}$ wat die Bybelgenootskap saamgestel het met die inhuldiging van hierdie Bybel word Breytenbach se presiesheid duidelik weerspieël wanneer hy verduidelik hoe hulle te werk gegaan het met die vertaling - dat hy in sy voorbereiding vir die vertaling seker gemaak het dat hy elke betekenis van elke woord in die brontaal geken het, voordat hulle vergader het om 'n spesifieke gedeelte te vertaal. Die eindresultaat was dan ookjuis dít wat hulle in gedagte gehad het: 'Bybelvertaling is ' $n$ lang, tydrowende proses, maar dit is so belangrik, en dit was ook al die tyd ons doel om uiteindelik 'n teks getrou aan die brontekste van die Bybel, maar in suiwer isiNdebele, in die hande van die mense te plaas', (Breytenbach soos aangehaal deur Turley 2012:1). Die Fakulteit Teologie aan die Universiteit van Pretoria het werksruimte en telefoonfasiliteite vir hierdie projek beskikbaar gestel, wat 'n weerspieëling is van die fakulteit se betrokkenheid by die gemeenskap, maar ook die fakulteit se strewe na inklusiwiteit.

\section{Afrikaanse Bybelvertalings en -vertalers \\ Oorsig}

Die Afrikaanse Bybelvertalingprojek het ietwat anders gefunksioneer as die komitee waarna hierbo verwys is. Dit was anders in die opsig dat dit 'n heelwat groter komitee was en bestaan het uit akademici van die drie gereformeerde susterkerke. Alle lede van die komitee wat deur hulle betrokke kerk aangewys is, moes kundig wees in Hebreeus of Grieks (Hermanson 2002:10).

6.https://www.bybelgenootskap.co.za/index.php/af/38-hulpmiddels/the-bible/110 isindebele-bybelvertaling

7.http://www.kaapkerk.co.za/wp/wp-content/uploads/2013/04/2014-11-20BYBELGENOOTSKAP-GROET-UITVOERENDE-HOOF.pd

8.https://www.youtube.com/watch?v=O_uHpKvEpMO
Die Bybelgenootskap verwys op hulle webwerf na enkele belangrike datums in die geskiedenis van Afrikaanse Bybelvertalings: ${ }^{9}$

Die eerste vertalers van gedeeltes van die Bybel was C.P. Hoogenhout, A. Pannevis en S.J. du Toit. In 1878 is die eerste Bybelboek (Markus) deur C.P. Hoogenhout in Afrikaans vertaal, alhoewel die vertaling nooit gepubliseer is nie, is dit wel beskikbaar in Kaapstad in die Nasionale Biblioteek van Suid-Afrika. In 1933 is die eerste Afrikaanse Bybel gepubliseer wat vertaal is deur Proff J.D. du Toit, E.E. van Rooyen, J.D. Kestell, B.B. Keet en dr H.C.M. Fourie en uitgegee deur die Britse en Buitelandse Bybelgenootskap in Londen.

Die Nuwe Afrikaanse Bybelvertaling is in 1983 uitgegee in Kaapstad deur die Bybelgenootskap van Suid-Afrika en die volgende persone het op die eindredaksie gedien: Proff E.P. Groenewald, J.P. Oberholzer, A.H. van Zyl, P.A. Verhoef, J.L. Helberg en W. Kempen.

Die eerste Bybel vir Dowes is in 2008 uitgegee in Bellville deur die Bybelgenootskap van Suid-Afrika. Dit is 'n Bybel wat spesiaal vertaal is om die beperkte woordeskat van gehoorgestremdes tegemoet te kom. Die redaksionele komitee vir hierdie vertaling het bestaan uit Proff J.P. Oberholzer, H.J.B. Combrink, H.C. van Zyl, F. Tolmie, C. van der Merwe en me E. Roux.

Die verskillende Afrikaanse vertalings uit die stal van die Bybelgenootskap word gekenmerk deur verskillende vertaaltegnieke en uitgangspunte. Naudé (2009:54-73) verwys na die verskillende vertalings en beklemtoon dat daar nie na die verskillende vertalings verwys kan word asof die een beter of meer betroubaar as die ander is/was nie. Hy wys daarop dat' $n$ vertaling wat deur die doeltaalgebruikers aanvaar word, reeds dui op ' $n$ vertaling van gehalte en dat die aanvaarding en die gebruik van die vertaling uiteindelik die sukses van die vertaling bepaal. ${ }^{10}$ Naudé (2009:58-68) ${ }^{11}$ gee ook 'n volledige uiteensetting van die sosio-raamwerk van kultuur, politiek, en tradisies wat bygedra het tot die eindproduk van die onderskeie vertalings.

\section{3-vertaling en 1953-hersiening}

Die eerste Afrikaanse Bybelvertaling is gebore uit 'n stryd vir Afrikaans (Dekker 1959:405; Venter 1999:61) en die eerste pogings tot 'n Afrikaanse Bybelvertaling in 1875 is in die wiele gery omdat Afrikaans toe nog nie 'n skryftaal was nie. Die Genootskap van Regte Afrikaners (GRA) het bygedra tot die

9.Hierdie is'n opsomming van die inligting soos op die Bybelgenootskap se webwerf verkry is: http://www.bybel.co.za/history. Sien ook Steyn 2003:12-13; 'Die Christelike Vrou', 1984 vir ' $n$ oorsigtelike bespreking van die Afrikaanse Bybelvertalings.

10.Dit kan moontlik die verklaring wees waarom die 1922 vertaling wat hoofsaaklik' $n$ Afrikaanse vertaling van die Nederlandse Statevertaling was, nooit deur Afrikaanse lesers aanvaar is nie. (Sien Naudé 2009:55; Strauss 2016:738 en Venter 1999:62 in die verband).

11.Sien ook Naudé 2005:167-179; Combrink 2014 en Venter 1999:61-74 vir 'n bespreking van die sosiohistoriese agtergrond van die Afrikaanse Bybelvertalings. 
skep van Afrikaans as 'n skryftaal (Van Rensburg 2015:322). ${ }^{12}$ In 1914 is Afrikaans aanvaar as 'n amptelike taal in skole en die eerste Afrikaanse Bybelvertaling loop hand-aan-hand met Afrikanersentimente (Venter 1999:61).

Op 22 November 1916 is 'n gesamentlike vergadering van twee Afrikaanse susterkerke gehou oor die Afrikaanse Bybelvertaling (die Nederduitsch Hervormde Kerk van Afrika [NHKA] was nie teenwoordig nie). In Junie 1919 is daar op 'n Algemene Kerkvergadering van die NHKA gedebatteer oor die sinvolheid van 'n Afrikaanse Bybelvertaling. ${ }^{13}$ Ds Jac van Belkum het beswaar aangeteken omdat die beplande vertaling uit die Nederlandse statevertaling sou geskied (Venter 1999:62-63). Hierdie selfde sentiment het tot uiting gekom toe dr H.C.M. Fourie wat in 1919 aangewys is as verteenwoordiger van die NHKA, op die vertalingskomitee summier bedank het omdat die vertaling nie uit die grondtale sou geskied nie. Sy standpunt is ondersteun deur die NHKA, veral nadat die proefpublikasie van die Vier Evangelies en Psalms in 1922 verskyn het. Dit was 'n verafrikaansing van die Statebybel en Fourie het dit beskryf as: 'stompstert-Nederlands' (Oberholzer 1970:17-18; Strauss 2016:738; Van Wyk 2000:38-39). Oberholzer (1970:17) is van mening dat dit Fourie se grootste bydrae tot Afrikaanse Bybelvertaling was. Hy sê dat as dit nie vir Fourie se weerstand teen ' $n$ vertaling van 'n vertaling was nie, sou daar nie vandag voor in die Afrikaanse Bybel die volgende woorde kon staan nie: 'oorgesit uit die oorspronklike tale'. In 1923 is daar dan besluit om die vertaling uit die grondtale te doen en J.J. Kühn bepleit in 1928 dat dit in 'n 'suiwer, idiomatiese Afrikaans ... soos 'n beskaafde Afrikaner praat, en nie stert-afgekapte, haasbek Hollands' moet geskied nie. (Strauss 2016:739; vgl Notule van die 42ste Algemene Vergadering van die NHKA, 1928). Die kommissie vir die vertaling het bestaan uit J.D. du Toit, B.B. Keet, J.D. Kestell, E.E. van Rooyen en H.C.M. Fourie en van die hersieners (reviseurs) was onder andere S. du Toit, C. van Gelderen, B. Gemser, S.P. Engelbrecht, J.J. Kühn, H.D. Broekhuizen en J.H. Greyvenstein (daar was in totaal 14 uit die verskillende kerke aangestel. Op 27 Augsutus 1933 is die eerste volledige Afrikaanse Bybel in gebruik geneem (Venter 1999:65-66).

Die 1933-vertaling het nog heelwat Nederlandse woorde bevat wat in die hersiene weergawe van 1953 omgeskakel is na Afrikaans (Strauss 2016:743; Van Rensburg 2015:328). J. du Toit (Totius) ${ }^{14}$ en B.B. Keet is hoofsaaklik aangestel om die hersiening te behartig; maar uit die geldere van die fakulteit Teologie aan die Universiteit van Pretoria het veral Proff B. Gemser en A.S. Geyser ook publikasies die lig laat sien om verbeterde vertalings voor te stel (Venter 1999:68). Die proses van hersiening sou ná 1953 uitloop op die Nuwe Afrikaanse

12.Sien Strauss (2016:733-745) vir'n volledige bespreking van die fases van Afrikaanse Bybelvertaling tot en met 1933 sowel as die aanvaarding en impak van die 1933-vertaling.

13.Sien Venter 1999:62-63 vir 'n bespreking van die onderskeie opinies tydens die vergadering

14.Sy seun, prof S Du Toit het ook ' $n$ groot bydrae gelewer toe die vertaling van veral Ou- Testamentiese boeke. Verwys na die artikel van D' Assonville (2004) vir ' bespreking van die drie geslagte van Du Toits wat betrokke was by Bybelvertaling.
Vertaling wat in 1983 gepubliseer is (Kritzinger 2013:7; Venter 1999:69).

\section{3-vertaling - aanloop en voltooiing}

Venter (1999) verwys soos volg na die aanloop tot hierdie vertaling: 'Op aandrang van die kerke, kultuurliggame en vakkundige verenigings het 'n kommissie van verteenwoordigers van die drie Afrikaanse kerke op 09 Oktober 1958 byeengekom om te beraadslaag oor 'n grondige hersiening van die vertaling' (bl 68). Prof B.B. Keet was die voorsitter en prof A.H. van Zyl die sekretaris van die Hersieningskommissie. In 1966 is prof Keet deur prof E.P. Groenewald opgevolg as voorsitter.

Die Fakulteit Teologie aan die Universiteit van Pretoria het op daardie stadium nog uit twee afsonderlike fakulteite bestaan, te wete Afdeling A (NHKA) en Afdeling B (NG Kerk). Verteenwoordigers van hierdie twee fakulteite is dus gekies uit hulle kerklike verteenwoordigers. Dié wat aanvanklik verkies is uit Afdeling A (NHKA), was onder andere: proff E.S. Mulder, A.S. Geyser (tot 1964, waarna hy deur prof S.P.J.J. van Rensburg vervang is) en A. van Selms (Venter 1999:68). Uit Afdeling B (NG Kerk dosente) was daar ook 'n strek verteenwoordiging van die fakulteit betrokke by die vertaling (Van der Merwe \& Vos 2009:3). Proff A.H. van Zyl en E.P. Groenewald was albei van hierdie fakulteit (Van der Merwe 2016:4; Van der Watt, Du Toit \& Joubert 2009:1-6).

In 1958-1959 verskyn 'n Afrikaanse Bybel met Verklarende aantekeninge waaraan heelwat persone meegewerk het. Die sameroeper was Ds J. Norval Geldenhuys en die doel was om 'n studiebybel vir individuele gelowiges saam te stel. Dit is gepubliseer deur die Verenigde Protestantse Uitgewers, met J.N. Geldenhuys as algemene redakteur. Vosloo wys daarop dat daar 31 medewerkers was vir hierdie publikasie. Voor in die publikasie word die volgende persone gelys as deel van die redaksie: B. Gemser, A.S. Geyser, E.P. Groenewald, J.H. Kroeze, Jac J. Müller, A.van Selms, W.J. Snyman, S. du Toit, P.A. Verhoef, P.F.D. Weiss en J.N. Geldenhuys. Venter (1999:68) voeg ook die volgende persone by: J.P. Oberholzer, E.S. Mulder, T.F.J. Dreyer ${ }^{15}$ en S.P.J.J. van Rensburg. Vosloo (2001:180-182) verwys ook na die bydrae van S.J. du Plessis.

Van Zyl (1984:23) verwys na die vertalingseminaar te Turfloop in Julie 1967, waar onder andere dr E. Nida en prof A.H. van Zyl lesings gegee het oor vertaalprobleme met die hersiening van die Afrikaanse Bybelvertaling. Volgens Van Zyl was dit hierdie lesings asook die insig van ds J.Th.M. de Jong van Arkel - die algemene sekretaris van die Bybelgenootskap op daardie stadium - wat die katalisator was vir ' $n$ nuwe vertaling in plaas van ' $n$ hersiening van die bestaande vertaling. Tydens hierdie seminaar is daar besluit om die Afrikaanse kerke te vra vir 'n nuwe vertaling en daar is 'n vertalingseminaar gereël vir Julie 1968, waar alle kerkleiers en moontlike vertalers teenwoordig was. Die besluit was eenparig (Van Zyl 1984:23) vir 'n dinamiesekwivalent nuwe vertaling (Combrink 2014:2).

15.Vosloo (2001:181) verwys ook na Mulder en Dreyer se bydrae. 
Lede van die aanvanklike Hersieningskommissie asook ander vertalers en medewerkers uit die drie Afrikaanse kerke is aangewys om aan die nuwe vertalingsprojek deel te neem. Van die kant van die Universiteit van Pretoria is die volgende persone aangewys: J.P. Oberholzer, C.J. Mans, A.J. Nolte en J.J. Engelbrecht (Venter 1999:68-69).

Venter (1999:69) noem die persone wat aan die proefvertaling van 1970 meegewerk het: A.H. van Zyl (1 Samuel); E.S. Mulder (Amos); J.P. Oberholzer (Maleagi); E.P. Groenewald (Johannes); en J.J. Muller (Filippense en Kolossense).

In 1970 is daar opnuut ' $n$ vertalingskommissie uit die kerke saamgestel. Prof G.M.M. Pelser was die assistentsekretaris en op die breë kommissie is B.J. Engelbrecht en F.J. van Zyl ook aangewys (Venter 1999:70). Op 'n later stadium is proff F.J. Botha, A.B. du Toit en W.S. Prinsloo (Afdeling B) ook betrek (Van der Merwe 2016:4; Van der Merwe \& Vos 2009:3; Van der Watt et al. 2009:1-6). Teen 1979 was die Nuwe Testament en die Psalms voltooi. Prof E.P. Groenewald was die voorsitter en prof J.P. Oberholzer die ondervoorsitter van die redaksionele komitee wat die vertaling afgerond het. A.P.B. Breytenbach ${ }^{16}$ en W.C. van Wyk ${ }^{17}$ is ook benoem as deeltydse vertalers met onder andere J.A. Loader, P.M. Venter, A.A. da Silva en J.H. Breytenbach (jr) as medewerkers (Venter 1999:71). Uit die geledere van die fakulteit Teologie aan die Universiteit van Pretoria het die volgende persone ook bydraes gelewer: proff A.G. van Aarde, J.A. du Randt, J.H. le Roux, M.H.O. Kloppers en J.H. Potgieter (fakulteit Geesteswetenskappe - Semitiese tale). ${ }^{18}$

Combrink (2014:2) wys daarop dat die 1983-vertaling 'n eerste beweging weg van die woord-vir-woord vertalings was, wat tot die helfte van die 20ste eeu as norm vir goeie Bybelvertaling gegeld het. Op 02 Desember 1983 verskyn die vertaling amptelik onder die eindredaksie van E.P. Groenewald, A.H. van Zyl, J.P. Oberholzer, J.L. Helberg, P.A. Verhoef en W. Kempen (Venter 1999:71)..$^{19,20}$

\footnotetext{
16. Hy het die grondvertaling vir Levitikus en Hosea gedoen (Kritzinger 2013:7).

17. Hy was verantwoordelik vir die vertaling van die Koningsboeke, Jeremia asook ' $n$ mede-vertaler van die Psalms (Oberholzer 2010f::10).

18.Van hierdie name is verkry uit ' $\mathrm{n}$ lys in die 'Verklarende Bybel' van wie die medewerkers en/of vertalers van die betrokke Bybelboeke was vir die 1983-vertaling. Hier is die volledige lys:

Ou Testament: A.H. van Zyl (Genesis, 1 Samuel, 2 Kronieke, Job, Psalms); F.C. Fensham (Eksodus); A.P.B Breytenbach (Levitikus); J van Schalkwyk (Numeri); M.H.O. Kloppers (Deuteronomium); D.N. Pienaar (Josua); F.N. Lion-Cache (Rigters); W.S. Prinsloo (Rut, Joël, Amos); H.F. van Rooy (2 Samuel); J.H. le Roux (1 \& 2 Konings); J.A. Naudé (1 Kronieke) W.C. van Wyk (2 Kronieke); H.J. Dreyer (Esra, Nehemia); W.T. Claassen (Ester); J.A. Loader (Spreuke); J.F.J van Rensburg (Prediker); D.S.R. du Toit (Hooglied); P.A. Verhoef (Jesaja 1-39); J.L. Helberg (Jesaja 40-66, Klaagliedere); F.F. Deist (Jeremia); J.P. Oberholzer (Esegiël, Maleagi); J.J. Burden (Daniël); W. Vosloo (Hosea); H.L. Bosman (Obadja, Nahum); J.H. Potgieter (Jona); P.M. Venter (Miga); P. Kruger (Habakuk); P.J. Nel (Sefanja); M.A.V van der Merwe (Haggai); F du T Laubscher (Sagaria).

Nuwe Testament: H.J.B Combrink (Matteus); F.J. Botha (Markus, Openbaring) P.P.A. Kotzé (Lukas); J.A. du Randt (Johannes); W. Nicol (Handelinge); A.B. du Toit (Romeine); J. Postma (1 Korintiërs); J.H. Roberts (2 Korintiërs); J.L. de Villier (Galasiërs); A.J.G. Dreyer (Efesiërs); B.J. Engelbrecht (Filippense); G.M.M. Pelser (Kolossense, Hebreërs). A G. van Aarde (1 \& 2 Tessalonisense). E.P. Groenewald (1 \& 2 Timse, He Judas); J.C. Coetzee (1, 2 \& 3 Johannes).

19.In die gedeelte hieronder word die erkenning, funksies en toekennings wat met hierdie gebeurtenis gepaard gegaan het, in besonder weergegee.

20.Oor die verdagmaking van hierdie vertaling op grond van hoofsaaklik politieke oortuigings skryf Oberholzer (2010e:27) sowel as Venter (1999:74).
}

\section{Erkenning en hoogtepunte vir Bybelvertalings en -vertalers}

In hierdie deel verwys ek graag na enkele gebeure in die geskiedenis wat spesifiek betrekking het op Bybelvertaling; geleenthede waar daar erkenning gegee is aan Bybelvertaling en-vertalers; asook ander vertalings wat ná die 1983-vertaling aandag geniet het.

Op 27 Augustus 1934 besluit die Raad van die Universiteit van Pretoria om eredoktorsgrade (DLitt) toe te ken aan die persone wat by die 1933-vertaling betrokke was. Hulle was: J.D. du Toit; H.C.M. Fourie; B.B. Keet; J.D. Kestell; en E.E. van Rooyen (Oberholzer 2010a:2).

Tydens die 53ste Algemene Kerkvergadering van die Nederduitsch Hervormde Kerk van Afrika (AKV van NHKA), op 09 Maart 1961 word daar aangekondig dat proff E.S. Mulder, A.S. Geyser en A. Van Selms benoem is om op die Kommissie vir die Hersiening van die Afrikaanse Bybelvertaling te dien (Oberholzer 2010b:3).

Op 11 Mei 1974 met die begrafnis van prof E.S. Mulder het verskeie persone die woord gevoer oor verskillende aspekte van prof Mulder se lewe en betrokkenheid by kerk en teologie. Prof E.P. Groenewald het onder andere namens die Kommissie van Bybelvertalers gepraat (Oberholzer 2010c:8).

Tydens 'n kuratoriumvergadering (NHKA) wat op 07 November 1974 gehou is, is daarvan kennis geneem dat prof W.C. van Wyk in die plek van prof E.S. Mulder benoem is as halftydse Bybelvertaler. Aangesien hierdie vertalings heelwat van prof Van Wyk se tyd in beslag sou neem, het die vergadering dit goedgekeur dat ds A.P.B. Breytenbach van die lesings in Ou-Testamentiese Wetenskap sou waarneem (Oberholzer 2010c:9).

Op 25 Oktober 1977 het die kuratoriumvergadering (NHKA) na aanleiding van 'n verslag van die dekaan en 'n aanbeveling van die Vergadering van Professore dit goedgekeur dat hulpdosente aangestel word veral om verligting te bring vir die belading van prof J.P. Oberholzer, wat voltyds betrokke was by die Bybelvertaling, maar ook sy lesings hanteer het en as voorsitter van die AKV van die NHKA gedien het. Hierdie saak is ' $n$ jaar later nog verder gevoer by 'n volgende kuratoriumvergadering: Op 03 Augustus 1978 is daar besluit dat daar bykomende hulp in prof Oberholzer se departement aangestel moet word nadat die Bybelgenootskap gevra het vir 'n voltydse vertaler (Oberholzer 2010c:15-16).

Tydens die kuratoriumvergadering wat op 24 Februarie 1983 gehou is, is besluit om die H.C.M. Fourie-erepenning aan prof Oberholzer toe te ken vir sy kerklike en akademiese bydrae, maar in besonder vir sy betrokkenheid by die Bybelvertaling. Die toekenning het plaasgevind by die 60ste AKV van 03 Mei 1983 en ds. J.J. Roos die voorsitter van die kuratorium wat die oorhandiging behartig het, het beklemtoon dat die toekenning in besonder aan prof Oberholzer gemaak word vir die uitsonderlike aandeel wat hy in Bybelvertaling gehad het (Oberholzer 2010d:3-4). 
Op 28 Augustus 1983 is die Goue Jubileumfees vir die Bybel in Afrikaans in Bloemfontein in die Callie Human sentrum gevier. Hierdie fees was in die formaat van 'n erediens wat deur Prof Oberholzer gelei is. Tydens hierdie fees is die aankondiging gemaak dat die Nuwe Afrikaanse Vertaling nog in dieselfde jaar sal verskyn. Dit sou dan vyftig jaar wees ná die eerste volledige vertaling wat in 1933 verskyn het (Oberholzer 2010d:5).

Die ingebruikneming van die Nuwe Teologiegebou asook die Luther- en Bybelfees het op 31 Augustus 1983 in die Musaion (Universiteit van Pretoria) plaasgevind. Die verrigtinge het bestaan uit: 'n paneelbespreking deur studente oor Luther se teologiese bydrae; die rektor, prof D.M. Joubert se oorhandiging van die Teologiegebou aan die twee dekane proff J.A. Heyns en B.J. Engelbrecht van die twee afdelings van die Fakulteit Teologie; besigtiging van die uitstallings; ' $n$ orreluitvoering deur Wim Viljoen van Luthermusiek en samesang van Lutherliede en Geneefse psalms onder leiding van dr D.J.C. van Wyk. Die feesviering is afgesluit deur proff J.P. Oberholzer en A.H. van Zyl wat die vyftig jaar ná die ingebruikneming van die Afrikaanse Bybelvertaling in herinnering geroep het (Oberholzer 2010d:5).

Op 02 Desember 1983 is die volledige ${ }^{21}$ Nuwe Afrikaanse Vertaling van die Bybel glansryk bekendgestel by die Bybelhuis in Kaapstad. Meneer Marais Viljoen, die staatspresident, het die eerste genommerde eksemplaar ontvang. Ten tye van die finalisering van die projek het die redaksie uit die volgende persone bestaan: proff E.P. Groenewald wat die voorsitter was; J.P. Oberholzer, die vise-voorsitter; A.H. van Zyl, die sekretaris; P.A. Verhoef; J.L. Helberg; en W. Kempen as taaladviseur (Oberholzer 2010d:5-6). Ander vertalers uit die geledere van die Universiteit van Pretoria wat betrokke was by die projek was onder andere proff G.M.M. Pelser; W.C. van Wyk; A.P.B. Breytenbach; F.J. Botha, A.B. du Toit en W.S. Prinsloo. ${ }^{22}$

Die Kommissie van die AKV van die NHKA het op 11 Mei 1983 hulle dank betuig aan die Eindredaksie van die Bybelvertaling asook die mede-vertalers uit die geledere van die NHKA by wyse van 'n dinee en die oorhandiging van oorkondes (Oberholzer 2010d:6). Die Senaat van die Universiteit van Pretoria het op 15 Augustus 1984 vir J.P. Oberholzer, W.C. van Wyk, G.M.M. Pelser en A.P.B. Breytenbach geluk gewens met die goue pennings en oorkondes wat hulle van die NHKA ontvang het vir Bybelvertaling. Hulle wens J.P. Oberholzer en A.H. van Zyl ook geluk met die oorkondes wat hulle vanaf die FAK en die Suid-Afrikaanse Akademie vir Wetenskap en kuns ontvang het vir hulle aandeel aan die Bybelvertaling (Oberholzer 2010d:7).

Op 31 Julie 1998 vind die bekendstelling van die Verwysingsbybel plaas in Kaapstad. Tydens die funksie is

21.Die Blye Boodskap is in 1975 gepubliseer en die Nuwe Testament en Psalms in 1979.

22.Sien o.a. (Oberholzer 2010d:5-6; Van der Merwe 2016:4; Van der Merwe \& Vos 2009:3; Van der Watt et al. 2009:1-6) eksemplare oordhandig aan die hoofsekretaris van die Bybelgenootskap (ds G. Kritzinger) en aan persone wat voorheen hoofsekretaris was: ds Gerit van der Merwe, ds Sep Boshoff en ds Donald Tolmie. Hierdie Bybel het ontstaan uit 'n projek wat op 27 Januarie 1992 begin is en bevat: '(1) die teks van die 1983-vertaling, (2) voetnote met kruisverwysings en aantekeninge, (3) 'n woordelys, (4) 'n lys van plekname, (5) 'n konkordansie, en (6) 'n stel kaarte' (Oberholzer 2010f.:2). Die Redaksionele Komitee vir hierdie projek was J.P. Oberholzer (voorsitter), P.A. Verhoef (ondervoorsitter), J.P. Louw, H.C. van Zyl en J.J.J . van Rensburg. Uit die geledere van die NHKA was die volgende medewerkers betrokke: 'A.P.B. Breytenbach (Lev, Hos), J.P. Oberholzer (Num, Eseg), J.H. Breytenbach (2 Kron), J.A. Loader (Est, Spr), L.C. Bezuidenhout (Job), F.J. Boshoff (Ob), P.M. Venter (Miga), A.A. da Silva (Nah), G.M.M. Pelser (2 Kor), P. van Staden (Fil)' (Oberholzer 2010f.:2).

Die Kuratorium verleen toestemming aan prof A.P.B. Breytenbach om as konsultant op te tree vir die vertaling van die Bybel in isiNdebele, tydens hulle vergadering op 25 November 1998 (Oberholzer 2010f:2).

Tydens die NHKA se 67ste AKV in die Aula van die UP, is die H.C.M. Fourie Erepenning op 26 September 2004 deur die vise-voorsitter van die kuratorium, dr E. van Eck, aan prof A.P.B. Breytenbach oorhandig vir sy bydrae tot die verryking van die reformatoriese teologie; sy aandeel in die totstandkoming van die Liedboek; maar veral sy bydrae tot Bybelvertaling (Oberholzer 2010f.:19).

Op 03 Februarie 2008 is die Afrikaanse Bybel vir Dowes bekendgestel in die Nederduitse Gereformeerde gemeente Worcester De la Bat by die Skool vir Dowes. Die vertaling is in 1997 begin en op 08 September 2005 afgehandel. Ds S.W. Viljoen het die skriflesing en verwelkoming behartig en prof J.P. Oberholzer die prediking. Ds Gerrit Kritzinger, die Uitvoerende hoof van die Bybelgenootskap, het eksemplare oorhandig aan die vertalers sowel as aan verteenwoordigers van gemeentes vir dowes. Vertalers vir hierdie projek was J.P. Oberholzer vir die Ou Testament met C. van der Merwe van Stellenbosch as adviseur. Vir die Nuwe Testament was daar H.J.B. Combrink van Stellenbosch en H.C. van Zyl en F. Tolmie van Bloemfontein. Daar was ook kundiges op die gebied van die dowetaal. Hulle was dr R. Hough (predikant vir die NG gemeente vir dowes in Bellville) asook E. Roux. Roux het haar hele loopbaan as onderwyseres gewy aan die onderrig van Afrikaans by die Skool vir Dowes op Worcester. In die proses is daar ook telkens advies verkry vanaf dowe persone (Oberholzer 2010f:27).

Die 75ste bestaansjaar van die Bybel in Afrikaans is vanaf 29 tot 31 Augustus 2008 in Bloemfontein gevier. Die vieringe is ingerig as 'n simposium oor Bybelvertaling wat ook afgesluit is met ' $n$ dinee en ' $n$ erediens op die Sondag. Ds Gerrit Kritzinger het die diens gelei en twee van die lede van die Eindredaksie van die 1983 vertaling, te wete J.P. Oberholzer en J.L. Helberg was ook teenwoordig by die vieringe (Oberholzer 2010f.:28). 

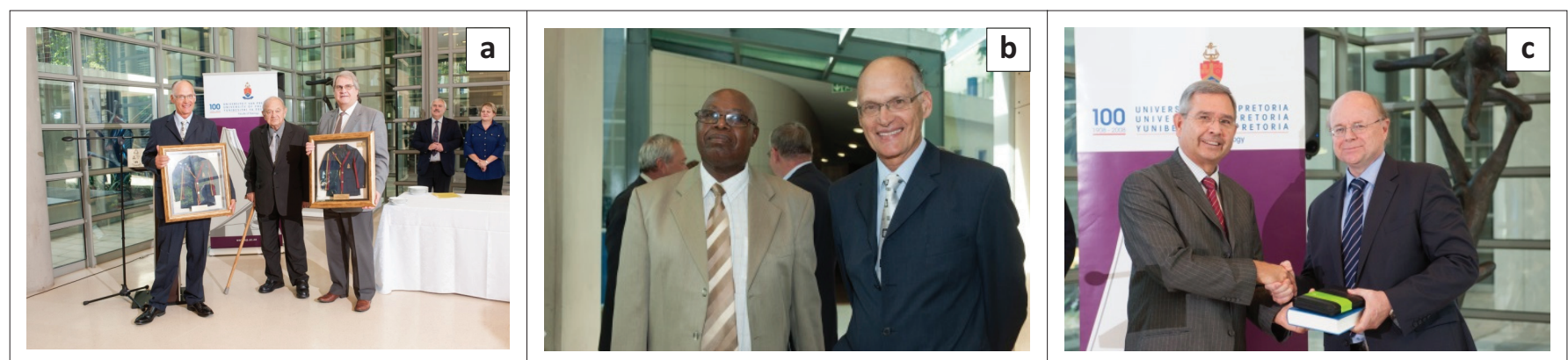

Source: Photos taken by Eyescape

(a) Dekaan, Prof J. Buitendag oorhandig geskenke aan Proff A.P.B. Breytenbach en J.P. Oberholzer tydens die funksie wat gehou is op 15 Maart 2013 ; (b) Prof A.P.B. Breytenbach (die projekleier vir die vertaling van die Ou Testament, maar ook die brontaalkenner en eksegeet vir die vertalingsprojek van die isNdebele Bybel) en Mnr Jeremia Mabena (hy was lid van die hersieningskomitee vir Gre

FIGUUR 1: Emeriti funksie (15 Maart 2013).

Op 09 September 2009 het dr D.J.C. van Wyk (jnr), op 'n Predikantevergadering, namens die komissie van die AKV ' $n$ oorkonde aan prof Oberholzer oorhandig, met spesifieke verwysing na sy bydrae in Bybelvertaling. Prof A.P.B. Breytenbach het op 10 September 2009 tydens ' $n$ middagete saam met die Kommissie erkenning gegee aan prof Oberholzer oor sy lewe en werk, waarna die Kommissie aan hom (Oberholzer) 'n geskenk oorhandig het (Oberholzer 2010f.:30).

Op 15 Maart 2013 is 'n funksie deur die Departement OuTestamentiese studies, by die Fakulteit Teologie aan die UP gehou om erkenning te gee aan twee van hulle emeriti (sien Figuur 1). Die baanbrekerswerk van Oberholzer ${ }^{23}$ en Breytenbach met betrekking tot Bybelvertaling is gevier en daar is aan hulle akademiese werk erkenning gegee. Die funksie was twee-ledig: Eerstens was daar by die fakulteit huldigingsredes gelewer oor die persone se werk en lewe. Prof Jurie le Roux het uitgewys dat Oberholzer deel was van 'n nuwe inspirasie vir Ou-Testamentiese studies in SuidAfrika, veral met betrekking tot kritiese teologiebeoefening. Dr Ananda Geyser-Fouché het verwys na Breytenbach se uitsonderlike kennis van die Hebreeus en sy skerp hermeneutiese omgang met Ou-Testamentiese tekste. ${ }^{24}$ Die tweede gedeelte van die program het in die glasfoyer van die Musaion plaasgevind, waar die gaste met verversings en vioolspel ingewag is. Tydens die geselligheid het die Uitvoerende hoof van die Bybelgenootskap, ds Gerrit Kritzinger, erkenning gegee aan die twee persone vir hulle bydrae tot inheemse Bybelvertaling. ${ }^{25}$

Prof Breytenbach was betrokke by die eerste volledige vertaling van die Bybel in isiNdebele wat in 2012 aan die Ndebele-gemeenskap oorhandig is. Prof Oberholzer was op sy beurt betrokke by 'n Bybel vir Dowes wat die beperkte woordeskat van gehoorgestremdes in ag neem en 'n Bybelvertaling vir hulle eiesoortige behoefte geskep het. Hy was ook betrokke by 'n Konkordansie van die Afrikaanse Bybelvertaling (1983). Beide professore was nóú betrokke by

23.Prof Oberholzer is minder as twee maande daarna, op 04 Mei 2013 op die ouderdom van 85 jaar oorlede.

24.Sien Geyser-Fouché (2013) vir'n verwerkte weergawe van hierdie referaat.

25. Kritzinger se referaat is verwerk in ' $n$ artikel: (verwerk deur Steyn, W.H.) in Die Hervormer, Mei 2013, bl 7. die Afrikaanse Bybelvertalings van 1983, en prof Breytenbach ook nog by die projek en die Bybel: 'n Direkte vertaling van die Bybelgenootskap van Suid Afrika.

Ds Gerrit Kritzinger het uit erkenning vir die Universiteit, die Fakulteit en die Departement se bydrae, eksemplare van dié twee Bybels aan die Universiteit oorhandig. Prof Niek Grové, die vise-rektor en registrateur het dit namens die Universiteit in ontvangs geneem. ${ }^{26}$ Die dekaan van die Fakulteit, Prof Johan Buitendag het aan die emeriti geskenke oorhandig.

Op 27 Junie 2013 het die Suid-Afrikaanse Akademie vir Wetenskap en Kuns die Ds Pieter van Drimmelenmedalje aan prof A.P.B. Breytenbach toegeken: 'Die Akademie het prof Breytenbach vereer omdat hy tans ' $n$ onvervangbare bydrae lewer tot die nuwe vertaling van die Bybel in Afrikaans en vir sy betrokkenheid by die jongste Afrikaanse Psalmberyming. Hy het 'n reuse bydrae gelewer tot die finale isiNdebele Bybel as projekleier en brontaalkenner' ${ }^{27}$

\section{Prof J.P. (Bart) Oberholzer se bydrae tot Bybelvertaling}

Prof Bart Oberholzer het so 'n enorme bydrae gelewer tot Bybelvertaling, dat dit 'n afsonderlike bespreking regverdig. In ds Gerrit Kritzinger ${ }^{28}$ se huldigingsrede aan prof Oberholzer, by die funksie wat op 15 Maart 2013 gehou is, het Kritzinger gesê dat prof Oberholzer vir byna 5 dekades feitlik sinoniem was met Afrikaanse Bybelvertalings. So vroeg as 1966 het hy betrokke geraak toe hy benoem is op die kommissie vir die hersiening van die Afrikaanse Bybelvertaling van 1933/1953. Die hersieningsproses het gou aan die lig gebring dat ' $n$ hersiening nie die antwoord sou wees nie, en dat' $n$ nuwe vertaling nodig was. Van die begin af was prof Oberholzer betrokke by die nuwe vertaling. In 1971, toe daar 'n proefvertaling verskyn het, was prof Oberholzer daarmee gemoeid. Sy grondige kennis van die Semitiese tale en werksywer het daartoe bygedra dat hy, in samewerking met prof Albertus van Zyl, 'n buitengewone

26.Sien onder andere: Tukkievaria - July 2013, vol 30(3), bi 4; en Tukkie 2013, bi 36 vir artikels oor die gebeure.

27.Tukkievaria, Julie 2013, vol 30(3), bl 4.

28.Sien die referaat (Kritzinger 2013) soos verwerk in 'n artikel in Die Hervomer van Mei 2013. 
groot aandeel in die konsepvertaling van die Ou Testament gehad het. Byna een derde van die Ou Testament se konsepvertaling vir die 1983-vertaling is deur hom gedoen. Dit lei dan ook daartoe dat hy op die Eindredaksie dien vir die nuwe Afrikaanse Bybelvertaling wat in 1983 gepubliseer is. Onder voorsitterskap van prof Oberholzer het die Redaksionele Komitee ná 1983 voortgegaan tot 1991 met sekere essensiële herformulerings van die vertaling. Die Suid-Afrikaanse Akademie vir Wetenskap en Kuns het in 1996 die Ds Pieter van Drimmelenmedalje aan prof Oberholzer toegeken vir sy bydrae as ondervoorsitter van die Eindredaksie asook vir sy aandeel in die 1983 Afrikaanse Bybelvertaling (Kritzinger 2013:7).

Tydens die Hersieningskommissie se vergadering in 1962 word die spelling van Bybelse name hanteer en Venter (1999:69) meld dat, vandat J.P. Oberholzer in 1965 lid geword het van hierdie kommissie, dit hoofsaaklik sy verantwoordelikheid was, hy heelwat artikels daaroor gepubliseer het en dat dit uiteindelik uitgeloop het op die Verwysingsbybel wat in 1998 gepubliseer is, waarvan hy mederedakteur was.

Nadat prof Oberholzer in 1991 die herformulerings-projek afgehandel het en met sy aftrede in 1992 is hy deur die Bybelgenootskap genader om mee te werk aan 'n Verwysingsbybel met die teks van die 1983-vertaling. In Januarie 1992 is die projek begin en prof Oberholzer was weer die voorsitter van die Redaksionele Komitee. Taalkundiges en teoloë het tot 1998 onder sy voorsitterskap gewerk om 'n voortreflike publikasie die lig te laat sien. Die Bybel bestaan uit twee bande en sluit die volgende in: Bybelteks met aantekeninge onder aan elke bladsy; 'n woordelys; pleknaamlys en 'n kernkonkordansie (Kritzinger 2013:7).

Prof J.P. Oberholzer sal veral onthou word vir sy aandeel in die Afrikaanse Bybel vir Dowes. Weereens was hy die voorsitter van die projek wat uit ses medewerkers bestaan het. Twee van die persone is kenners op die gebied van dowetaal en het die vertaling deurentyd by die dowes getoets. Die Bybel beslaan 2038 bladsye met ongeveer 18000 verklarende voetnotas en 74 illustrasies. Die vertaling is in verstaanbare Afrikaans uit die grondtale vertaal. Die verstaanbare taal van hierdie Bybel het sy gewildheid so laat toeneem, dat die Bybel tans uitgegee word as 'Die Bybel vir Almal'. In die Konteks van Oktober 2009 (bl. 3) beskryf prof Francois Tolmie prof Oberholzer se aandeel in die projek soos volg:

As voorsitter het hy nie net die hele projek beplan en bestuur nie, maar deurgaans kragdadige leiding gegee. As voorsitter was hy ook by elke gesamentlike vertaalsessie goed voorberei en het hy die vertaalproses op 'n kundige manier gelei, en gehelp om gepaste vertaalkeuses te maak in gevalle waar daar verskillende vertaalopsies was. Die komiteelede het onder die indruk gekom van prof Oberholzer se woordvaardigheid, en was dikwels verstom oor sy vermoë om uit die vuis uit gepaste formulerings voor te stel.

Tolmie (2009:3) wys daarop dat prof Oberholzer die hele Ou Testament uit Hebreeus en Aramees vertaal het en dat prof
Christo van der Merwe (Universiteit van Stellenbosch) die enigste persoon was wat bydraes gelewer het, en dat dit alleen was om prof Oberholzer se vertaling te kontroleer. Tolmie wys ook op die noukeurigheid waarmee prof Oberholzer die vertaling aangepak het, asook op sy verstommende vaardigheid in al die grondtale van die Bybeltekste:

Afgesien van die vertaling van die ou Testament, het hy ook die vertaling van die Nuwe-Testamentgedeeltes soos deur die Nuwe Testamentici voorgestel, telkens deeglik deurgewerk en alternatiewe voorgestel waar nodig. Hy het die finale teks van al die Bybelboeke verskeie kere deurgewerk om kleiner foute te identifiseer en aanpassings voor te stel.

Prof Oberholzer was ook gemoeid met 'n projek wat in 2011 begin is om 'n Engelse Bybel vir dowes daar te stel. In 2006 is daar begin met 'Die Bybel in Afrikaans: 'n Direkte vertaling' en prof Oberholzer was ook daarby betrokke, veral as eksegeet vir die boek Esegiël. Hy was ook lank voorsitter van die Kerklike Advieskomitee (KABA) van die Bybelgenootskap. Hierdie komitee adviseer die Bybelgenootskap oor die Bybel in Afrikaans en maak aanbevelings. Ten tye van sy dood was hy 'n erelid van hierdie komitee en was hy vir 47 jaar betrokke by Bybelvertaling in Suid-Afrika.

Naas sy werk as Bybelvertaler, was prof Oberholzer ook akademikus, dosent, predikant, kerkman en kerkleier. Hoe hy dit reggekry het om al die hoede meestal gelyktydig op te sit, het menige kollega verstom. Hy het uitgestaan as 'n persoon met 'n ongelooflike werkywer en 'n baie skerp intellek. Dit word weerspieël in sy betrokkenheid op alle terreine..$^{29}$ Die persoon, werkwyse en teologie wat prof J.P. Oberholzer gekenmerk het, word opgesom deur Venter (1999:73), ${ }^{30}$ asook in die huldigingsbundel wat die HTS in 1992 aan hom opgedra het. ${ }^{31}$ Die bundel was ook die Fakulteit Teologie se 75 ste feesbundel. In die bundel verwys Venter (1992:113) veral na Oberholzer se teologie, maar Smit (1992:13), die visekanselier en rektor se huldigingswoord asook Van Wyk (1992:17) se waarderingswoord beeld die werk en verantwoordelikheid wat Oberholzer op homself geneem het, asook sy ongekende werkvermoë, ten beste uit.

29.Daar word telkens na Oberholzer se gemoeidhede verwys: Volgens die jaarversla. van 19 September 1972 van die Fakulteit was daar 29 studente vir BD ingeskryf en 31 vir DD. In die verslag word genoem dat Prof Oberholzer naas sy ander 31 vir DD. In die verslag word genoem dat Prof Oberholzer naas sy ande werksaamhede ook Bybelkunde doseer het (Oberholzer 2010c:3). Op 11 Mei 1974 word Prof Mulder se begrafnis gehou in die kerkgebou van Pretoria gemeente en Prof Oberholzer voer die woord namens die NHKA (Oberholzer 2010c:8). Prof W.C van Wyk word in die plek van Prof Mulder benoem as halftydse Bybelvertaler. Dit behels dat prof Van Wyk nie meer vier lesings per week kan waarneem nie. Ds Breytenbach en prof Van Wyk sou daarna elk een lesing per week waarneem en prof Oberholzer vier (Oberholzer 2010c:9). Op 25 Oktober 1977 word daar tydens 'n kuratoriumvergadering verslag gedoen oor die fakulteit se werksaamhede: 'Die dekaan het onder andere ook verslag gedoen oor die belading van J.P. Oberholzer wat' $n$ voltydse program met die Bybelvertaling het naas sy werk as professor en as voorsitter van die Algemene Kerkvergadering ...' (Oberholzer 2010c:15). Oberholzer is vanweë sy betrokkenheid by die Bybelvertaling gevra om die diens te lei tydens die Goue Jubileumfees van die Bybel in Afrikaans op 28 Augustus 1983 (Oberholzer 2010d:5). Op 21 Mei 1985 het die Fakulteit se jaarverslag vermeld dat Oberholzer weer voltyds betrokke geraak het in sy departement, na voltooiing van die Bybelvertalingsprojek (Oberholzer 2010d:7).

30.Sy lewenstrewe om die Kerk te dien, sy besondere aanleg in antieke tale, sy belangstelling in tekste, sy aanleg vir noukeurigheid, sy vermoë om hard te werk en sy gawe om kristalhelder te formuleer, het hom'n onmisbare lid van die vertaalspan gemaak.

31.HTS 48(1\&2) 1992. 
Smit (1992) sê dat Oberholzer eerstens kerkman was:

Sy bydrae op hierdie terrein is indrukwekkend. Hy dien ook vanaf 1964 tot 1989 op die Kommissie van die Algemene Kerkvergadering ... Vanaf 1973 tot 1989 is hy voorsitter ... In die tyd neem hy die inisiatief vir die vestiging van die Kerklike Instituut vir Toerusting van ampsdraers en lidmate (KITAL) en is hy betrokke by verskeie belangrike ontwikkelings binne die Kerk ... By sy talle kerklike en universitêre verpligtinge en sy betrokkenheid in die gemeenskap, vind hy ook nog tyd om oor etlike jare ' $n$ substansiële bydrae te maak tot die nuwe vertaling van die Bybel. (bl. 13-15)

Van Wyk (1992) bied 'n volledige en omvattende blik op Oberholzer se lewe, werk, betrokkenheid, teologie en publikasies. Hy verwys na Oberholzer as teoloog, predikant en ook:

... as kerk- en gemeenskapsleier van formaat. In dié unieke tydperk in die Hervormde Kerk se geskiedenis kon hy as uitsonderlike begaafde 'n ewe unieke rol speel. Hy het dié geleentheid benut en 'n bydrae gelewer wat die eer van God en die heil van die kerk gedien het. Daar is nie ' $n$ leiersposisie in die Hervormde Kerk wat hy nie beklee het nie: vanaf Ringsvergaderings, die Kuratorium, die kommissie van die Algemene Kerkvergadering tot hoogleeraar en dekaan van die Fakulteit Teologie (Afd A), aan die Universiteit van Pretoria. Daarby kon hy ' $n$ prominente rol speel as medewerker aan die tweede vertaling van die Bybel in Afrikaans. As daar soms gevoel is dat sy invloed as mens in die Nederduitsch Hervormde Kerk vanweë al dié posisies groter is as wat vir die kerk gesond is, dan is dit eenvoudig omdat hy die bekwaamheid daartoe gehad het en in intellek, ewewig, werkkrag en teologiese insig ver bokant dié rondom hom uitgestyg het (bl 18). (bl. 17-55)

In Oktober 2009 verskyn daar twee artikels in die Konteks waarin daar na Oberholzer se werk verwys word. Die een is 'n artikel van Louise Geyser: 'Die essensie van professor Bart Oberholzer' en die ander een is 'n artikel waarin Francois Tolmie sy ervaring van Oberholzer as vertaler en sy bydrae tot die Bybel vir Dowes meedeel: 'Die vertaling van die Bybel vir Dowes' (Oberholzer 2010f.:30).

\section{Nuutse Bybelvertalings:' $n$ Direkte vertaling}

In die 1990's is die Bybelgenootskap van Suid-Afrika (BSA) deur KABA genader vir 'n Afrikaanse Bybelvertaling wat nader aan die bronteks is (Combrink 2014:2; Van der Merwe 2014:8). Nóg die vertaalkundige uitgangspunte van die 1933/1953-vertaling, nóg dié van die 1983-vertaling kon voldoen aan die behoefte van 'n 'verstaanbare 'kerkbybel' wat so na as moontlik aan die bronteks bly ...' (Van der Merwe 2014:8). Van der Merwe (2012; 2014; 2016), sowel as Combrink (2014) gee 'n breedvoerige verduideliking van die proses wat die BSA gevolg het met betrekking tot marknavorsing; vertaalkunde; aanstelling van verantwoordelike persone en komitees; asook opleidingseminare. ${ }^{32}$ Combrink (2014:4) noem dat daar duidelik onderskei moet word 'tussen vertaling deur eksegete, intravertaling deur die intravertalers en hersiening deur brontaalkenners, ander eksegete, taalkundiges en letterkundiges.'

Combrink (2014) wys op die fases waardeur die vertalings gaan. Fase een verduidelik hy soos volg: 'Alle eksegete is nie ewe vaardig in Afrikaans nie. Daar is van die begin af die nouste samewerking tussen eksegeet en intravertaler sodat die vertaling reeds in Fase 1 nie die werk van slegs eksegete en brontaalkenners is nie. Daar is ook aanvaar dat ander taalkundiges en letterkundiges se insette reeds vroeg in die proses verkry moet word' (bl. 3). Fase twee is 'n verdere interne hersiening wat gedoen word deur taalkundiges en letterkundiges, waarna dit aan die onderskeie Redaksionele komitees (Ou Testament; Nuwe Testament; Deuterokanonieke boeke) voorgelê word. Die Redaksionele komitees bestaan gewoonlik uit minstens agt lede, waarvan twee brontaalkenners is, twee eksegete, twee of meer letterkundiges, 'n Afrikaanse taalkundige en 'n vertaalkundiges en/of taalpraktisyn, asook die projekleier. Fase drie is 'n eksterne hersiening deur lesers wat deur kerke benoem is vir kommentaar op die vertalings, kommentaar wat op die webblad deur lesers gelewer word, word ook in hierdie fase in ag geneem. Fase vier is 'n kontrole vir konsekwentheid en fase vyf is ' $\mathrm{n}$ finalisering van die teks deur die Begeleidingskomitee (Combrink 2014:3-4).

Van der Merwe (2014) wys op die verwagting waaraan hierdie vertaling moet voldoen:

In die geval van die nuwe Bybel in Afrikaans lui die onderhandelde vertaalopdrag soos volg: 'Skep 'n goed verstaanbare, bronteksgeoriënteerde Afrikaanse vertaling van die Bybel wat geskik is vir die voorlesing en gebruik in eredienste, sowel as vir kategese, Bybelstudie en persoonlike gebruik'. Die skopos van die vertaling is dat dit 'n direkte vertaling moet wees'. (bl. 299)

Van der Merwe (2014) verduidelik wat bedoel word met 'n 'direkte vertaling':

Volgens dié kommunikasiemodel is 'n spreker en hoorder se kodes nie al wat by die kodering en dekodering van taaltekens betrokke is, soos die kodemodel wat Nida gebruik het, geïmpliseer het nie. Die spreker en hoorder se konseptuele wêrelde speel ook 'n primêre rol ... Die fundamentele verskil tussen ' $n$ direkte en ' $n$ indirekte vertaling is dat die vertaalde teks self in eersgenoemde nie by die moderne leser se konseptuele wêreld hoef in te pas nie. Die keersy is egter dat die konseptuele wêreld van die teks gerekonstrueer moet word... en die konseptuele wêreld van die kerklike lesers ... verbreed moet word ... deur middel van inleidings tot die Bybelboeke, voetnotas, kantaantekeninge, kaarte, kruisverwysings en 'n woordelys. (bl. 299-300)

Beide Combrink (2014:3) en Van der Merwe (2014) wys op die inklusiwiteit van die nuwe vertaling. Van der Merwe stel dit soos volg: 'Medewerkers aan die vertaling moes so verteenwoordigend moontlik wees wat ouderdom, geslag, ras en veral kerke betref - in teenstelling met die 1983-vertaling, wat hoofsaaklik deur verteenwoordigers van die drie 'wit' gereformeerde susterkerke gedoen is' (bl. 296). 
Van der Merwe (2016:3-10) wys op die kompleksiteit van taal en dat twee van die grootste uitdagings met so ' $n$ vertaling die inkongruensie van kulturele verwysingsraamwerke asook die verskille in die formele en funksionele kenmerke van die tale is. Hy sê dat die uitdaging van 'n direkte vertaling beklemtoon hoe min 'n mens regtig weet en hoeveel daar nog uitgevind moet word. Hy sê dat dit nuwe uitdagings skep: onder ander noop dit Bybelvertalers om meer realisties te wees wanneer hulle aan kerke die implikasies en verwagtinge van so 'n vertaling meedeel; dit dui op die dringende nodigheid om meer uit te vind oor die Bybel se konseptuele wêreld; en dit lei tot hernude studie en opleiding op die terrein van Bybelvertaling (bl 10).

Hierdie vertaling het ook nie sonder verdag- en afmaking gepaard gegaan nie. In Maart 2012 het prof A.P.B. Breytenbach wat voltyds betrokke is ${ }^{33}$ by hierdie vertaalprojek op hierdie verdagmakery van die vertaling van veral Ou-Testamentiese tekste gereageer. ${ }^{34}$ Op 30 Oktober 2012 het die vergadering van die KABA kennis geneem van die pogings en die volgende besluit is eenparig geneem:

Die vergadering

1. vind dit baie jammer dat pogings aangewend word om die Bybel: 'n Direkte Vertaling (BDV) verdag te maak en by voorbaat in diskrediet te bring op grond van die manier waarop tekste in die $\mathrm{Ou}$ Testament, wat in die Nuwe Testament as Messiaans aangedui word, weergegee word en distansieer hom van al sodanige pogings;

2. bely onomwonde, saam met die hele vertaalspan en die Bybelgenootskap van Suid-Afrika (BSA), die Godheid van Christus en sy verlossingswerk;

3. betuig sy dank teenoor die BSA vir die besluit dat 'n tweede uitgawe van die vertaling (soos versoek deur sommige kerkgenootskappe) goedgekeur word waar hoofletters gebruik sal word in Ou-Testamentiese tekste wat in die Nuwe Testament as Messiaans aangedui word;

4. versoek kerkgenootskappe om hul lidmate bewus te maak van die BDV en die webblad www. bybeldirektevertaling.co.za onder hulle aandag te bring;

5. verseker die vertaalspanne en redaksionele komitees van hul voorbidding vir die vertaling van die BDV.

6. bedank die BSA vir die wyse waarop hulle die saak met betrekking tot die verdagmaking van die BDV hanteer.

Ons vertrou dat hierdie duidelike besluit verder sal bydra om kerkgenootskappe, kerke en lidmate gerus te stel ten opsigte van die integriteit en geloofsoortuiging van die vertaalspan en die Bybelgenootskap van Suid-Afrika met betrekking tot die vertaling wat tans gedoen word.

Vanweë die feit dat die oorgrote meerderheid kerkgenootskappe wat Afrikaans as voertaal gebruik by hierdie vertaling betrokke is, vertrou ons dat die vertaling instrumenteel sal wees om die

33.Kritzinger (2013:7) noem dat Breytenbach een van die kernlede van die vertaalspan is; dat hy eksegeet en intravertaler is en ook dien op die Begeliedings- en Redaksionele komitee (Ou Testament). Hy wys daarop dat Breytenbach direk betrokke is by dite (Ou Testanent). Hy wys daarop dat Breytenbach direk betrokke is by die volgende boeke: Deuteronomium, 2 Samuel, Jesaja, Hosea, Obadja, Jona asook die Psalms. Kritzinger noem verder dat Breytenbach in 2013 voltyds aangestel is om groter momentum te gee aan die vertaalprojek van die Ou
Testament en dat hy die voorsitter van die KABA is.

34.Breytenbach se volledige antwoord kan gelees word by: http://www. bybeldirektevertaling.co.za/index.php/vraag-a-antwoord/75-enkele-opmerkingsoor-die-kritiek-op-die-vertaling-van-die-bybel-in-afrikaans
Kerk en Koninkryk baie wyd te dien en dat dit duidelik en helder die Goeie Nuus sal oordra 'sodat julle kan glo dat Jesus die Christus is, die Seun van God, en sodat julle deur te glo, in sy Naam die lewe kan hê' (Johannes 20:31). In diens van die Woord Ds Gerrit Kritzinger Uitvoerende Hoof. ${ }^{35}$

Hierdie Bybelvertaling is nog in wording, maar in 2014 is die Nuwe Testament sowel as Psalms bekend gestel, sodat die publiek en kerklike lesers steeds kommentaar kon lewer (Combrink 2014:8). Die vertalings van die verskillende Bybelboeke word op die Bybelgenootskap se webwerf geplaas, soos wat dit beskikbaar raak, sodat daar terugvoer daaroor gegee kan word. ${ }^{36}$ Volgens die nuutste (31 Maart 2017) nuusbrief van die projek - Die Bybel: 'n Direkte vertaling (BDV) is die projek goed op koers met die oog daarop om die BDV teen die einde van 2020 bekend te stel. Die Nuwe Testament se fase 3 is reeds in 2015 afgehandel, maar aangesien daar nog heelwat kommentaar daarop ontvang is, is daar op 03 tot 07 Maart 2017 nog 'n byeenkoms gehou deur die Redaksionele komitee van die Nuwe Testament om die bywerkings te oorweeg. Die werk aan die Nuwe Testament is egter vir die huidige afgesluit en enige ander kommentaar sal vir 'n toekomstige hersiening oorweeg word. Die Ou Testament se fase een is volledig afgehandel en fase twee is reeds ver gevorder - die Redaksionele Komitee is besig om Jesaja te redigeer waarna Jeremia en Job nog oorbly. Hulle hoop om dit teen einde 2017 af te handel. Die Deuterokanonieke boeke se fase een en twee is reeds afgehandel en fase drie is byna voltooi (Combrink 2017:1).

\section{Slotgedagtes}

Sedert die reformasie is Bybelvertaling gekenmerk as 'n voortdurende proses van hersiening. Afrikaanse Bybelvertaling is die afgelope 100 jaar in 'n groeiproses, en verskillende vertaalteoretiese- as taalkundige verskuiwings het 'n rol gespeel. Getrou aan die aard van Bybelvertaling is elke vertaling voorlopig. Dit het gegeld vir die 1933/1953-vertaling, vir die 1983-dinamies-ekwivalente vertaling, vir die Bybel vir Dowes, en sal ook geld vir die Direkte Bybelvertaling wanneer dit gepubliseer word.

Hierdie proses van Bybelvertaling is alleen moontlik gemaak deur die visie en konsekwentheid van die Bybelgenootskap van Suid-Afrika sowel as die bydraes van talle Bybelvertalers wat met integriteit en toegewydheid die teks toegelaat het om vanuit 'n antieke konteks te praat in 'n konteks wat voortdurend verander.

Met die eeufeesviering van die Fakulteit Teologie aan die Universiteit van Pretoria, kan die fakulteit ook met betrekking tot Bybelvertaling terugkyk en erken dat hierdie fakulteit 'n leeueaandeel gehad het, en steeds het in die vertaling van die Bybel in Afrikaans. Hierdie fakulteit het Bybelvertalers en teoloë gelewer wat 'n wesenlike bydrae tot Bybelvertaling gemaak het. Persone wat in dié verband in herinnering

35.http://www.bybeldirektevertaling.co.za/index.php/vraag-a-antwoord/76verdagmaking-van-die-bybel-n-direkte-vertaling - 01 November 2012

36.http://www.bybeldirektevertaling.co.za/ 
geroep word is: prof B Gemser ${ }^{37}$ wat gesien word as die grondlegger van die wetenskaplike studie van die $\mathrm{Ou}$ Testament (Mulder 1951:95) en saam met prof Van Selms beskou word as die vaders van Ou-Testamentiese studies aan hierdie fakulteit; prof A. van Selms wat deur Oberholzer (1992:68) beskryf word as 'n '... innig gelowige prediker, fors en vaardig met tong en pen, die ensiklopediese geleerde wat in baie opsigte die laaste van sy soort maar dan ook 'n keurvoorbeeld van die soort was... met 'n vrolike enorme werkywer'; prof E S. Mulder wat deur Breytenbach (1992:111) beskryf word as die voorloper vir historiese-kritiese navorsing wat dit moontlik gemaak het vir akademici om onbevange navorsing te doen en resultate bekend te maak; prof A.S. Geyser met sy krities-historiese benadering tot tekste en sy aandrang op 'n wesenlike hersiening van die Afrikaanse Bybelvertaling; (Van Aarde 1992:164, 167) prof S.P.J.J. van Rensburg met sy histories-grammatikale invalshoek op tekste, en wat nie bang was 'dat die wetenskaplike bestudering van die Bybel die gesag van die Bybel sou ondermyn nie' (Engelbrecht 1992:185); prof A.H. van Zyl met sy historiese-kritiese bestudering van die tekste (Le Roux 1988:165); prof E.P. Groenewald wat gesien is as die vader van Nuwe-Testamentiese studies in Suid-Afrika (Sien Van der Watt et al. 2009:2); prof J.P. Oberholzer wie se filologiese navorsing van onskatbare waarde was, veral vir Bybelvertaling (Venter 1992:120; asook die aanhaling van Groenewald 1984:6: 'Hy het hom laat ken as 'n uitnemend geskoolde Ou-Testamentikus wat met gemak die Hebreeuse of Aramese grondteks, die konkordansie op die grondteks en die kommentare kon hanteer... met kundigheid en onderskeidingsvermoë toegeligte parallelle uit die $\mathrm{Ou}$ Testament byhaal en met logiese beredenering sy standpunt glashelder stel); prof A.B. du Toit wat die eerste akademikus in die suidelike halfrond was wat verkies is as die president van die Studiorum Novi Testament Societas en bekend gestaan het as die doyen van Nuwe-Testamentici in Suid-Afrika (Van der Watt et al. 2009:2); prof G.M.M. Pelser wat die belangrikheid van die historiese benadering beklemtoon het, een van die voorlopers was met die historiese Jesusnavorsing, en sterk aanklank gevind het by Bultmann (Boshoff 1992:198, 201, 207); prof A.G. van Aarde wat gekenmerk word deur sy dialektiese- en eksistensiële teologie wat van verskeie eksegetiese benaderings in sy teksondersoek gebruik maak (Van Eck 1992:217; Van Eck \& Dreyer 2011:1); prof A.P.B. Breytenbach wat homself tuis vind 'by die breë stroom van dialektiese en krities-gelowige teoloë' (GeyserFouche 2013:5); prof F.J. Botha wat bekend was vir sy noukeurige presiesheid en sy uitstekende kennis van NuweTestamentiese Grieks (Van der Watt et al. 2009:3); prof W.S. Prinsloo wat sterk gefokus het op teksimmanente eksegese en wat die behoud van die dialektiese spanning in teologieë in die $\mathrm{Ou}$ Testament bepleit het teenoor die versmelting of verklaring van verskille (Le Roux 1988:170, 173).

Goeie Bybelvertalers is persone wat uitmuntende kennis het van die Bybel se grondtale en ook passievol is oor die brontekste. Hulle besit die literêre vaardigheid om akkurate formulerings te maak en 'n soepelheid in hulle omgang met die teikentaal se idioom. Hulle word verder gekenmerk as persone wat met perfeksionistiese presiesheid weer-en-weer teruggaan na die teks en die vertaling; dit heroorweeg; wik; weeg; en aanhou verfyn totdat hulle oortuig daarvan is dat die vertaling so na aan die oorspronklike teks se bedoeling is as wat die eie taal toelaat. Dit is in wese niks anders as voortdurende hervorming en die sola scriptura wat eie is aan die Reformasie, nie.

Labuschagne (2008:1188) wys daarop dat die reformasie met betrekking tot die interpretasie van die Bybel, 'n oop ongearriveerde benadering voorstaan, wat dui op voortdurende terugkeer en voortdurende herbesinning; dat daar dus nooit 'n finale uitspraak of uitleg kan wees nie. Hierdie aspek van Skrifverstaan is dan ook die wesenskenmerk van Bybelvertaling en behoort te alle tye so te wees.

Bybelvertaling word deur Luther beskryf as 'n kuns wat nie deur enige iemand bemeester kan word nie, maar dat dit 'n sekere tipe karakter verg: 'Daarvoor is nodig 'n regte, vroom, getroue, toegewyde, versigtige, Christelike, geleerde, ervare en geoefende hart' (Steyn 2009:2). Elkeen van hierdie kwaliteite is nodig om van iemand 'n goeie Bybelvertaler te maak.

In 'n tyd waar dit belangrik geword het om na skrywers en hulle werke te verwys, is dit opvallend dat die Bybelgenootskap van Suid-Afrika 'n beleid van geen vermelding het, sodat meeste Afrikaanse Bybels nie verwys na die vertalers wat dit moontlik gemaak het om daardie Bybel in die leser se taal beskikbaar te maak nie. Hulle werk word agter die skerms verrig met 'n nederige besef van die ontsettende verantwoordelikheid. Dit alleen maak dit nodig om van tyd tot tyd stil te staan en erkenning te gee aan hierdie baanbrekers wat ure bestee het en nog steeds daaraan bestee om hierdie versigtige en onbaatsugtige werk met soveel toewyding te verrig. Hierdie gees van onbaatsugtige diens is veral 'n karaktertrek wat by meeste Bybelvertalers opval. Dit is duidelik uit 'n opmerking wat prof J.P. Oberholzer gemaak het: 'Ek sê nog steeds dat dit seker die grootste voorreg is wat aan 'n mens gegee kan word om jou met Bybelvertaling besig te hou. Ek het baie voorregte in my lewe gehad, binne die Kerk en daarbuite, maar ek sal graag my deelname aan die Bybelvertaling uitsonder as een van die grootse seëninge wat daar in my lewe was' (Kritzinger 2013:7).

\section{Erkenning}

Die outeur betuig opregte waardering aan Prof A.P.B. Breytenbach, wat ten spyte van 'n baie druk program, sy weg oop gesien het om die artikel te kontroleer vir die feitelike korrektheid daarvan.

\section{Mededingende belange}

Die outeur verklaar dat hy geen finansiële of persoonlike verbintenis het met enige party wat hom nadelig kon beïnvloed het in die skryf van hierdie artikel nie. 


\section{Literatuurverwysings}

Boshoff, P.B., 1992, 'Gerhardus Marthinus Maritz Pelser', HTS Teologiese Studies/ Theological Studies 48(1\&2), 197-211.

Breytenbach, A.P.B., 1992, 'Egge Simon Mulder, hoogleraar 1956-1970', HTS Teologiese Studies/Theological Studies 48(1\&2), 101-112. https://doi.org/ 10.4102/hts.v48i1/2.2379

Chemorion, D.C., 2009, 'Considerations for acceptability in bible translation', Verbum et Ecclessia 30(2), Art. \#343, 1-5, https://doi.org/10.4102/ve.v30i2.343

Combrink, H.J.B., 2014, 'Die Bybel:'n Direkte Vertaling', DF Malherbe-Gedenklesing 27 Mei 2014, viewed 05 April 2017, from http://www.bybeldirektevertaling.co.za/ images/stories/docs/df\%20malherbe-gedenklesing.pdf

Combrink, H.J.B., 2017, 'Die Bybel: 'n Direkte Vertaling', Nuusbrief 26, 1-2, viewed 05 April 2017, from http://www.bybeldirektevertaling.co.za/images/stories/ Nuusbrief/BDV_Nuusbrief_26.pdf

D’Assonville, V.E., sr., 2004, 'Drie geslagte Du Toit-Bybelvertalers', Act Theologica Supplementum 5, 202-216.

Dekker, G., 1959, 'Die wonder van Afrikaans. Totius en die Bybelvertalers', Koers dee XXVI, 405-409.

Die Bybel Met Verklarende Aantekeninge, 1990, Verenigde Protestantse Uitgewers, Kaapstad.

Die Christelike Vrou, 1984, Die Bybel in Afrikaans 18781933 1983, bl 6-7, 10.

Engelbrecht, J.J., 1992, 'SPJ van Rensburg, hoogleraar 1963-1972', HTS Teologiese Studies/Theological Studies 48(1\&2), 183-195.

Geyser-Fouché, A.B., 2013, 'Jotas en titel het betekenis - die krities-eksegetiese en teologiese bydrae van Andries Breytenbach as Bybelvertaler', HTS Teologiese Studies/ Theological Studies 69(1), Art. \#1982, 1-6, https://doi.org/10.4102/hts. v69i1.1982

Groenewald, E.P., 1984, 'Prof JP Oberholzer', Die Hervormer 6.

Hermanson, E.A., 2002, 'A brief overview of Bible translation in South Africa', Acto Theologica (Suppl 2), 6-18.

House, J., Ruano, R.M. \& Baumgarten, N., (eds.), Translations yearbook of the international association for translation \& intercultural studies, IATIS, Seoul.

Keating, C., 2001, John Wycliffe's motivation for translating the Scriptures into his vernacular language, Fuller Theological Seminary, Phoenix, AZ.

Kritzinger, G., 2013, (verwerk deur Steyn, W.H.), 'Ons huldig twee baanbrekers in Bybelvertaling', Die Hervormer Mei, bl 7.

Labuschagne, J.P., 2008, 'Die Reformasie en Skrifinterpretasie: Die nuwe wat die Reformasie gebring en ook moontlik gemaak het' HTS Teologiese Studies/ Theological Studies 64(3), 1187-1212. https://doi.org/10.4102/hts.v64i3.76

Le Roux, J.H., 1988, 'Die departement Ou Testament, 'n halwe eeu', Skrif en Kerk 9(2), 160-180. https://doi.org/10.4102/ve.v9i2.988

Le Roux, J.H., 2009, 'Old Testament Studies: The story of a departement', Verbum et Ecclesia 30(3), Art.\#182, 1-9. https://doi.org/10.4102/ve.v30i3.182

Moore, R.K., 2014, 'The case for Bible translation, viewed in historical perspective', The Bible Translator 65(1), 77-87, https://doi.org/10.1177/ 2051677013518300

Mulder, E.S., 1951, 'Die wetenskaplike betekenis van die werk van Professor B. Gemser', HTS Teologiese Studies/Theological Studies 7(2/3), 85-96. https://doi. org/10.4102/hts.v7i2/3.3628

Murray, D.E., 2000, 'Changing technologies, changing literary communities?', Language Learning \& Technology, 4(2), 39-53.

Naudé, J.A., 2005, 'The Afrikaanse Bible translations and the formation of cultural, political and religious identities in South Africa', in J. House, R.M. Ruano \& N. Baumgarten (eds.), Translations yearbook of the international association for translation \& intercultural studies, pp. 167-179, IATIS, Seoul.

Naudé, J.A., 2009, “'Soos ' $n$ hamer wat ' $n$ rots vermorsel”: Die Afrikaanse Bybel van 1933 as vertaling', Acta Theologica $54-73$.

Oberholzer, J.P., 1988, 'Barend Jacobus Engelbrecht - 'n Oorsig en waardering', HTS Teologiese Studies/Theological Studies 44(2), 265-274. https://doi.org/10.4102/ hts.v44i2.2201

Oberholzer, J.P., 1992, 'Adrianus van Selms, deeltydse dosent 1938-1962', HTS Teologiese Studies/Theological Studies 48(1\&2), 67-82. https://doi.org/10.4102/ hts.v48i1/2.2377

Oberholzer, J.P., 2010a, 'Twee Afdelings Van Een Fakulteit 1934-1940', in 'Honderd Jaar Kerk en Teologiese Opleiding: ' $\mathrm{n}$ Kroniek van die Hervormde Kerk', HTS Teologiese Studies/Theological Studies, 66(3 Suppl 9), Art. \#919, 1-8. https://doi. org/104102/hts.v66i3.919

Oberholzer, J.P., 2010b, 'Ekumeniese isolasie en interne stryd 1961-1970, in 'Honderd Jaar Kerk en Teologiese Opleiding: ' $\mathrm{n}$ Kroniek van die Hervormde Kerk', HTS Teologiese Studies/Theological Studies 66(3 Suppl 9), Art. \#936, 1-21. https://doi. org/104102/hts.v66i3.936

Oberholzer, J.P., 2010c, 'Evaluering en selfinterptetasie 1971-1980', in 'Honderd Jaa Kerk en Teologiese Opleiding: 'n Kroniek van die Hervormde Kerk', HTS Teologiese Studies/Theological Studies 66(3 Suppl 9), Art. \#921, 1-20. https://doi.org/ 104102/hts.v66i3.921
Oberholzer, J.P., 2010d, 'Groei, vooruitskouing, terugskouing 1981-1987', in 'Honderd Jaar Kerk en Teologiese Opleiding: 'n Kroniek van die Hervormde Kerk', HTS Teologiese Studies/Theological Studies 66(3 Suppl 9), Art. \#935, 1-15. https://doi. org/104102/hts.v66i3.935

Oberholzer, J.P., 2010e, 'Rasionalisering en optimalisering 1988-1997' in 'Honderd Jaar Kerk en Teologiese Opleiding: 'n Kroniek van die Hervormde Kerk', HTS Teologiese Studies/Theological Studies 66(3 Suppl 9), Art. \#934, 1-35. https://doi. Teologiese Studies/Theolog
org/104102/hts.v66i3.934

Oberholzer, J.P., 2010f, 'Terug by Een Ekumeniese Fakulteit 1998-2009' in 'Honderd Jaar Kerk en Teologiese Opleiding: 'n Kroniek van die Hervormde Kerk', HTS Teologiese Studies/Theological Studies 66(3 Suppl 9), Art. \#110, 1-31. https://doi. org/104102/hts.v66i3.110

Smit, D., 2015, 'Reading the Bible through the ages? Historical and hermeneutical perspectives', Stellenbosch Theological Journal 1(2), 175-194. https://doi.org/ 10.17570/stj.2015.v1n2.a08

Smit, P.J., 1992, 'JP Oberholzer - "n Huldigingswoord deur die vise-kanselier en rektor Universiteit van Pretoria', HTS Teologiese Studies/Theological Studies 48(1\&2), 13-15.

Steyn, W.H., 1995, 'Amptelike Bybelwerk 175 jaar in Suid-Afrika', Konteks, Aug, 2-3.

Steyn, W.H., 2003, 'Die Bybel in Afrikaans', Konteks Okt, 12-13.

Steyn, W.H., 2009, 'In die begin was die Woord...', Konteks Okt, 2.

Stolt, B., 2014, 'Luther's translation of the Bile', Lutheran Quaterly vol xxviii, 373-400.

Strauss, P., 2016, 'Die geskiedenis, aanvaarding en impak van die Afrikaanse Bybel van 1933 - 'n oorsig', Tydskrif vir Geesteswetenskappe 56(3), 733-745, https://doi. org/10,17159/2224-7912/2016/v56n3al

Tolmie, F., 2009, 'Die vertaling van die Bybel vir dowes', Konteks Okt, 3.

Tukkie, 2013, Autumn, 19(1), 36, viewed n.d., from https://www.slideshare.net/ UniversityPretoria/tukkie-2013-autumn

Tukkievaria, 2013, Julie, 30(3), 4, viewed n.d., from https://www.slideshare.net/ UniversityPretoria/tukkievaria-2013

Turley, M., 2012, 'Bybelvertaling voltooi', Tydlose nuus, Die Erdekruik/The Vessel, Jaargang 14(5), 1.

Van Aarde, A.G., 1992, 'A S Geyser, teologiese dosent 1946-1961', HTS Teologiese Studies/Theological Studies 48(1\&2), 159-182. https://doi.org/10.4102/hts. v48i1/2.2388

Van der Merwe, C.J.H., 2012, 'The Bible in Afrikaans: A direct translation - A new type of church Bible', HTS Teologiese Studies/ Theological Studies 68(1), Art. \#1204, 1-8, https://doi.org/10/4102/hts.v68i1.1204

Van der Merwe, C.J.H., 2014, 'Direkte vertaling van die Bybel as antieke teks: net ' $n$ nuwe benaming vir ' $\mathrm{n}$ stokkerige woordelikse vertaling?', Litnet Akademies Jaargang 11(3), Desember 2014, 290-315.

Van der Merwe, C.J.H., 2016a, 'How 'direct' can a direct translation be? Some perspectives from realities of a new type of church Bible', HTS Teologiese Studies/ Theological Studies 72(3), a3233, htpps://doi.org/10.4102/hts.v72i3.3233

Van der Merwe, J., 2016b, 'Partners in history: The Dutch Reformed Church and theological training at the University of Pretoria: 1938-2000', HTS Teologiese Studies. Theological Studies 72(4), a3416. https://doi.org/10,4102/hts.v72i4.3416

Van der Merwe, J. \& Vos, C.J.A., 2009, 'The history of the faculty of theology at the University of Pretoria: A Dutch reformed perspective 1938-2008', Verbum et Ecclesia 30(3), Art. \#132, 1-9, https://doi.org/10.4102/ve.v30i3.132

Van der Watt, J., Du Toit, A. \& Joubert, S., 2009, 'The Departement of New Testament Studies (Dutch Reformed Church) 1938-2008', Verbum et Ecclesia 30(3), Art. \#181, 1-6, https://doi.org/10.4102/ve.v.30i3.181

Van Eck, E., 1992, 'A G van Aarde as teoloog (1979-)', HTS Teologiese Studies/ Theological Studies 48(1\&2), 213-252. https://doi.org/10.4102/hts.v48i1/2.2395

Van Eck, E. \& Dreyer, Y., 2011, 'Editorial to the Van Aarde Festschrift', HTS Teologiese Studies/Theological Studies 67(1), Art. \#1040, 1-5, https://doi.org/10.4102/hts. v67i1.1040

Van Rensburg, C., 2015, 'Oor die eerste 50 jaar se maak aan Standaardafrikaans', Tydskrif vir Geesteswetenskappe Jaargang 55(3), 319-342. https://doi.org/ 10.17159/2224-7912-2015-v55n3a1

Van Wyk, D.J.C., (snr) 1992, 'JP Oberholzer: 'n Waardering', HTS Teologiese Studies/ Theological Studies 48(1\&2), 17-55.

Van Wyk, D.J.C., (snr), 2000, '1933 - Die Bybel in Afrikaans', Konteks Maart, 38-39.

Van Zyl, A.H., 1984, 'Die aanleiding tot die Nuwe Afrikaanse Bybelvertaling', Skrif en Kerk 5(1), 23-38.

Venter, P.M., 1992, 'JP Oberholzer: Professor in en hoof van die Departement OuTestamentiese Wetenskap (Afd A), 1971-1992', HTS Teologiese Studies/ Theological Studies 48(1\&2), 113-136.

Venter, P.M., 1999, 'Twee Afrikaanse Bybelvertalings en die Hervormde Kerk' in D.J.C van Wyk, 20ste Eeu Hervormde Teologie, bl 61-74.

Verklarende Bybel (1983 vertaling). 1ste uitg, 1989, Lux Verbi, Kaapstad.

Vosloo, W., 2001, 'Hoe om die Bybel beter te verstaan: Verklarings van die Bybel in Afrikaans', Verbum et Ecclessia, 22(1), 178-190. https://doi.org/10.4102/ve.v22i1.632

Webartikels: https://www.youtube.com/watch?v=O_uHpKvEpM0, www.bybel.co.za/ history 